\title{
Pengembangan Media Komunikasi Digital Dewan Masjid Indonesia (DMI) Kota Semarang Melalui Pemetaan Masjid Berbasis Android Untuk Meningkatkan Integrasi Informasi Organisasi
}

\section{Development of Digital Communication Media of Dewan Masjid Indonesia (DMI) Semarang Through the Mapping of Android-Based Mosques to Enhance Organizational Information Integration}

\author{
Muhammad Syaifur Rohman ${ }^{1}$, Galuh Wilujeng Saraswati ${ }^{2}$, Nurul Anisa Sriwinarsih ${ }^{3}$ \\ ${ }^{1,2,3}$ Fakultas Ilmu Komputer, Universitas Dian Nuswantoro \\ E-mail: ${ }^{1}$ syaifur@dsn.dinus.ac.id,²nurulanisasw@dsn.dinus.ac.id, \\ ${ }^{3}$ galuhwilujengs@dsn.dinus.ac.id
}

\begin{abstract}
Abstrak
Dewan Masjid Indonesia (DMI) adalah organisasi tingkat nasional dengan tujuan untuk mewujudkan fungsi masjid sebagai pusat ibadah, pengembangan masyarakat dan persatuan umat salah satunya melalui aplikasi yang dibuatnya. Namun aplikasi tersebut masih banyak kekurangan terutama mengenai informasi masjid di Kota Semarang. Berdasarkan permasalahan tersebut DMI kota Semarang bekerjasama dengan Pemerintah Kota semarang dengan mengembangkan aplikasi pencarian masjid yang digunakan untuk menemukan lokasi masjid terdekat dari posisi pengguna. Untuk melengkapi aplikasi DMI kota Semarang untuk menyajikan detail informasi dan data seluruh masjid di kota semarang maka perlu adanya pendataan titik kordinat masjid. Titik koordinat ini nantinya akan menghubungkan titik koordnat masjid dengan posisi pengguna shingga dapat memandu jamaah untuk sampai kemasjid yang dituju. Dengan menggunakan media komunikasi Grup Whatsapp, maka pendataan titik kordinat masjid akan dikirimkan oleh para takmir yang tergabung didalamnya. Program pengabdian masyarakat ini bermanfaat bagi Pengurus Daerah DMI Kota Semarang, Para Takmir Masjid dan masyarakat Semarang dengan luaran berupa aplikasi Dewan Masjid Indonesia (DMI) yang dapat memberikan lokasi masjid masjid dengan jarak terdekat melalui Media Komunikasi grup Whatsapp untuk pengelolaan produk dan kegiatan masjid Kota Semarang. Selain itu melalui Media Komunikasi grup Whatsapp yang sudah disediakan, pelayanan informasi untuk jamaah terkait dengan penggunaan aplikasi bisa dilakukan setiap saat.
\end{abstract}

Kata kunci: Location Based Service, Marketing Communication, Aplikasi Android, Dewan Masjid Indonesia

\begin{abstract}
Dewan Masjid Indonesia (DMI) is a national-level organization with aims to improve the mosque as a center for worship, community development and community unity, one way through the application they made. But the application has deficiency especially regarding information on mosques in Semarang City. Based on these problems DMI Kota Semarang in cooperation with Semarang City Government by developing a mosque search application that is used to find the nearest mosque location from the user's position. To complete the DMI Kota Semarang application with detailed information and data on all mosques in Semarang city, the mosque coordinate data collection point are needed. This apps later will connect the coordinate point of the mosque with the position of the user so that it can guide users to get to the destination mosque. By using the Whatsapp Group communication media, the data collection point of the mosque's coordinates will be sent by the takmir who are members of it. This community service
\end{abstract}


program is useful for the Regional Administrators of DMI Kota Semarang, Mosque Management and Semarang community with an output in the form of DMI Kota Semarang application that can provide the location of the mosque at the closest distance through Whatsapp group Communication Media for the management of products and activities of the Semarang City mosque. In addition, through the WhatsApp group Communication Media that has been provided, information services for pilgrims related to the use of the application can be done at any time.

Keywords: Location Based Service, Marketing Communication, Android Application, Dewan Masjid Indonesia

\section{PENDAHULUAN}

Dalam rangka pengembangan wilayah, setiap kota wajib memperkenalkan bebagai asset potensial. Semarang merupakan ibu kota Provinsi Jawa tengah sekaligus kota metropolitan terbesar ke lima setelah medan. Semarang memiiliki luas wilayah $373,70 \mathrm{~km}$ dengan jumlah penduduk mencapai 2,5 juta jiwa. Penduduk semarang mayoritas adalah suku jawa dan menganut agama islam. Selain sebagai kota metropolitan, Semarang juga terkenal dengan keanekaragaman wisatanya [1]. Selain itu kota ini memiliki beragram asset potensial yang belum di ketahui oleh masyarakat karena kurangnya sosialisasi [2].

Tempat ibadah merupakan asset potensial kota semarang yang harus ada disetiap daerah untuk memenuhi kebutuhan rohani penduduk [3]. Keberadaan tempat ibadah dikota Semarang khususnya masjid, banyak dijadikan sebagai tempat wisata karena keindahan masjid dan beberapa fasilitas yang di tawarkan masjid tersebut. Banyaknya jumlah masjid di Kota Semarang dan keberadaanya yang menyebar membuat penduduk lokal maupun wiatawan kesulitan menuju lokasi masjid, sehingga diperlukan sistem informasi yang menyediakan informasi mengenai lokasi masjid, luas bangunan serte keterangan lainya.

Salah satu kesulitan bagi para wisataan yang berkunjung ke Kota Semarang khususnya yang berasal dari luar kota dan beragama islam adalah mencari lokasi untuk tempat ibadah yang terdekat dengan posisinya. Dikarenakan tidak semua tempat wisata yang mereka kunjungi menyediakan fasilitas masjid. Sehingga diperlukan sebuah informasi yang memandu para wisatawan untuk mencari lokasi tempat beribadah [4].

Penggunaan teknologi informasi dan komputer menghasilkan sebuah solusi sistem informasi Geografis untuk menentukan titik lokasi masjid khususnya di Kota Semarang [3]. Dengan kemampuan tersebut baik penduduk lokal maupun wisatawan dapat mengakses infomasi tentang keberadaan masjid dengan cepat. Sistem Informasi spatial juga dapat menyajikan informasi khususnya informasi lokasi masjid, alamat, luas bangunan yang di lengkapi dengan gambar atau foto masjid dengan jelas dan akurat.

DMI (Dewan Masjid Indonesia) adalah organisasi tingkat nasional dengan tujuan untuk mewujudkan fungsi masjid sebagai pusat ibadah, pengembangan masyarakat dan persatuan umat. DMI mempunyai beberapa cabang kepengurusan yang tersebar disetiap daerah. DMI juga sudah tersedia Mobile Application. Selain ketersediaan informasi di berbagai Application, DMI juga rutin melakukan kerjasama, pelatihan dan juga workshop. Namun setelah beberapa review ada beberapa kekurangan yang perlu diperbaiki seperti beberapa menu yang tidak bisa berjalan didalam Mobile Application dan kurang adanya pengembangan masrayakat didalamnya terutama di bidang pemberdayaan ekonomi. Ketersediaan Mobile Application untuk DMI di tiap daerah seperti di kota semarang juga masih diperlukan untuk mengenalkan DMI lebih dekat lagi dengan masyarakat Indonesia yang mayoritasnya Muslim (pemeluk agama Islam).

Berdasarkan permasalahan diatas, penulis melakukan pembuatan sistem Informasi Geografis (SIG) yang dapat membantu meyelesaikan masalah yang di hadapi[3], yaitu Pemerintah Kota Semarang belum meliliki sebuah sistem terkomputerisasi penentuan titik lokasi tempat ibadah khususnya masjid. DMI kota Semarang dapat bekerjasama dengan 
Pemerintah Kota semarang dalam mengembangkan SIG pencarian masjid menggunakan google maps yang digunakan untuk menemukan lokasi masjid terdekat dari posisi pengguna [5]. Untuk melengkapi pembuatan aplikasi DMI kota Semarang untuk menyajikan detail informasi dan data seluruh masjid di kota semarang maka perlu adanya pendataan titik kordinat masjid. Titik koordinat ini nantinya akan menghubungkan titik koordnat masjid dengan posisi pengguna shingga dapat memandu pengguna untuk sampai kemasjid yang dituju. Dengan menggunakan media komunikasi Grup Whatsapp, maka pendataan titik kordinat masjid akan dikirimkan oleh para takmir yang tergabung didalamnya.

\section{METODE PELAKSANAAN}

Pemasalahan mendasar yang dihadapi oleh Pengurus Daerah DMI Kota Semarang adalah sebagai berikut:

1. Kurangnya pengetahuan dan kompetensi dibidang teknologi informasi mengenai pemetaan Masjid di Kota Semarang.

2. Belum tersedianya aplikasi dan sistem yang membatu para Pengurus Daerah DMI Indonesia dalam mengatur dan memenejemen seluruh takmir masjid di Kota Semarang.

3. Minimnya informasi yang diperoleh Pengurus Daerah DMI Kota Semarang mengenai aktivitas kajian islam, kegiatan rutin masjid dan pemberdayaan ekonomi masyarakat sekitar masjid, yang di karenakan tidak ada platform yang digunakan untuk menampung semua informasi tersebut.

Oleh karena itu, dalam pelaksanaan pengabdian ini perlu adanya Pengembangan Media Komunikasi Digital untuk DMI Kota Semarang yang dapat melakukan Pemetaan masjis berbasis aplikasi mobile android yang bertujuan meningkatkan integrasi Informasi Organisasi. Dengan menggunakan aplikasi mobile juga kegiatan tukar informasi seperti pemberian dan update data bisa berlangsung secara realtime. Melalui program pengabdian kepada masyarakat ini, permasalahan yang dihadapi oleh Pengurus Daerah DMI Kota Semarang akan dapat diselesaikan dengan adanya Media Komunikasi Digital ini.

Berdasarkan analisis permasalahan tersebut maka solusi yang ditawarkan dalam program pengabdian ini adalah peningkatan integrasi informasi anatara takmir masjid, anggota DMI dan jamaah dalam hal aktvitas dan kegiataan keagaaman yang diselengarakan oleh masjid di Kota Semarang. Dengan demikian, target luaran dari program pengabdian ini adalah pemetaan koordinat masjid ini digunakan untuk membangun aplikasi Dewan Masjid Indonesia Kota Semarang menggunakan fitur location whatsapps dan google maps yang akan di hubungkan ke website Dewan Masjid Indonesia.

Terget yang ingin di capai dalam kegiatan pengabdian kepada masyarakat ini:

1. Merpermudah masyarakat baik dari dalam/luat Kota Semarang dalam menemukan infromasi letak masjid terdekat dengan posisinya.

2. Membuat sebuah platform aplikasi yang digunakan sebagai media komunikasi sehingga seluruh kegiatan masjid se-Kota Semarang dapat terintegrasi dengan baik.

\section{HASIL DAN PEMBAHASAN}

Pemetaan Kordinat untuk Aplikasi DMI Kota Semarang ini terdiri dari tiga tahapan. Tahap pertama dari program kemitraan pengabidan masyarakat ini adalah koordinasi dengan PD DMI Kota Semarang untuk merencanakan agenda pengabdian masyarakat berupa pelatihan penggunaan aplikasi Dewan Masjid Indonesia Kota Semarang, penyusunan panita pengurus, pembagian penanggung jawab dan pembentukan grup whatsapp sebagai media komunikasi antar PD dan takmir. Pada tahap pertama ini diberikan sosialasi tentang penggunaan aplikasi 
mobile ini dan bagaimana nantinya melakukan pemetaan kordinat masjid diseluruh kota semarang. Acara pertemuan ini selain dihadiri oleh PD DMI Kota Semarang juga dihadiri oleh akademisi, dan perwakilan regional tiap kecamatan. Berikut ini gambaran kegiatan pelatihan yang telah di laksanankan:
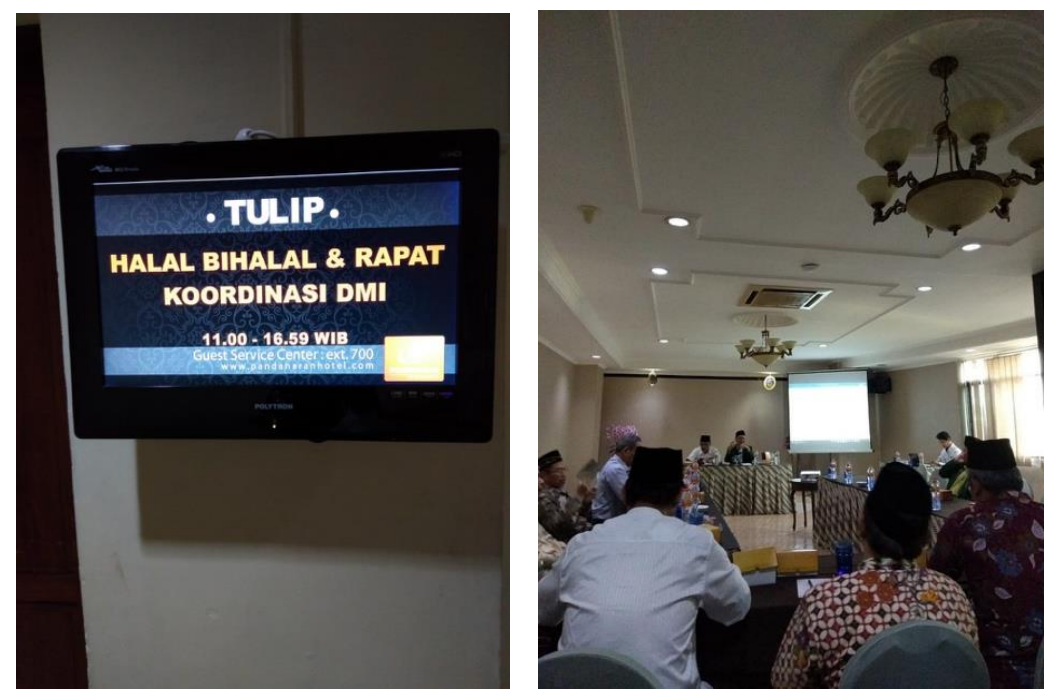

Gambar 1 Rapat Koordinasi DMI

Tahap Kedua adalah mengadakan sosialisasi dan pelatihan sesuai dengan hasil pertemuan pertama dengan PD DMI Kota semarang, akademisi dan perwakilan tiap regional kecamatan. Dalam tahapan ini perserta pelatihan ini mendapatkan pengetahuan berupa gambaran penggunaan Penggunaan aplikasi DMI Kota Semarang. Semua peserta pelatihan memberikan respon baik terhadap program pelatihan ini dan memberikan saran berupa tambahan fitur dalam aplikasi dan adanya buku panduan untuk memahami penggunaan aplikasi DMI Kota Semarang. Peserta berharap dengan adanya aplikasi ini kegiatan masjid dan pengembangan ekonomi potensial masyarakat di sekitar masjid dapat berjalan dengan baik dan lancar sehingga dengan adanya kegiatan ini dapat meningkatkan pendapatan masyarakat dan termasuk pendapatan anggaran untuk administrasi masjid demi kebermanfaatan semua makhluknya.

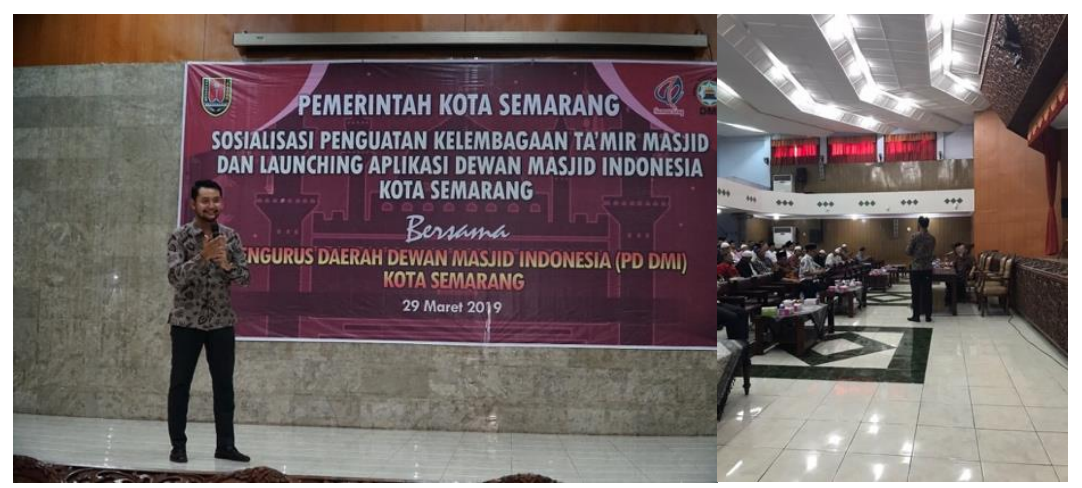

Gambar 2 Rapat Koordinasi DMI

Selanjutnya diberikan invitation link sehingga para takmir akan tergabung dalam grup yang sama dengan PD DMI Kota Semarang. Kegiatan penggunaan media komunikasi grup whatsapp ini telah dilaksanakan dan berjalan dengan lancar sesuai dengan rencana, hal ini dibuktikan dengan antusiasme peserta pelatihan terhadap aplikasi yang dihasilkan sehingga banyak informasi masjid yang dapat dikumpulkan seperti detail informasi masjid, foto masjid dan yang 
paling utama adalah kordinat masjid yang dibagikan oleh takmir yang tergabung dalam DMI Kota Semarang.

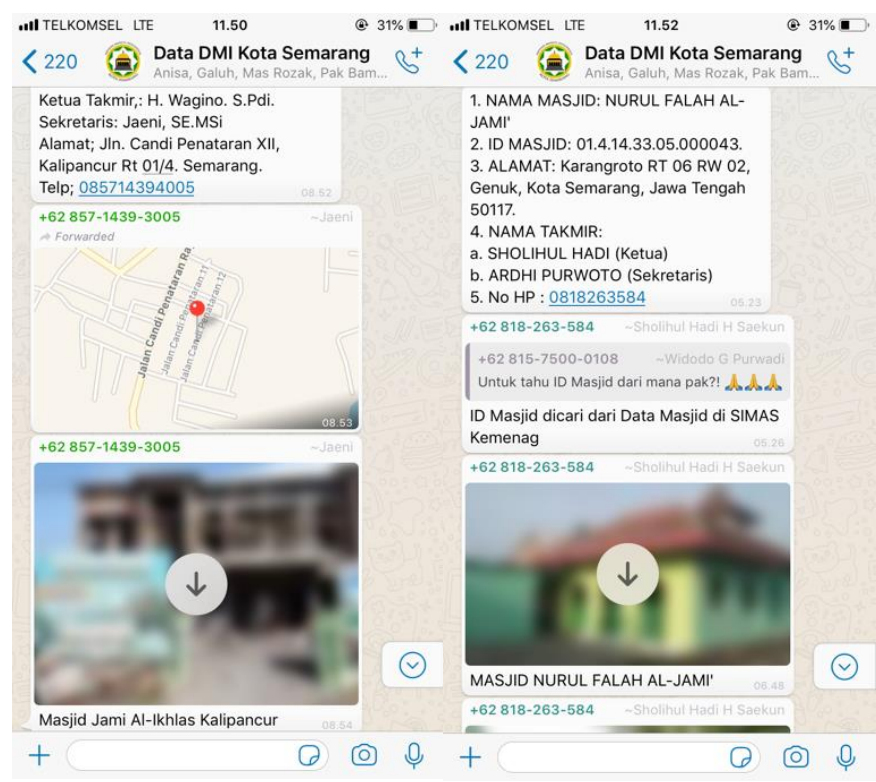

Gambar 3 Bimbingan melalui Media Komunikasi Grup Whatsapp

Tahap terakhir berupa bimbingan teknis yang di berikan kepada peserta yang ditunjukan oleh gambar 3. Hasil yang di peroleh dari tahapan ini berupa peserta program pengabdian masyarakat ini memamahami dan menggunakan aplikasi DMI Kota Samarang untuk menginformasikan kegiatan pada setiap masjidnya sehingga para jamaah akan mudah menuju masjid tersebut melalui penunjuk arah yang sudah disediakan oleh aplikasi, serta peserta pengabdian masyarakat ini mendapatkan makan siang. Bukti pelaksanaan kegiatan bimbingan teknik. Berikut ini adalah kesimpulan dari target output dari program pengabdian masyarakat:

Tabel 1.Target dan Output Pengabdian Masyarakat

\begin{tabular}{|l|l|l|l|}
\hline No & Tahap & Output & Target \\
\hline 1 & $\begin{array}{l}\text { Tahap survei dan koordinasi: } \\
\text { Menganalisa masalah mitra dan } \\
\text { merencanakan agenda pelaksanaan } \\
\text { Pengabdian Masyarakat }\end{array}$ & $\begin{array}{l}\text { Melalui pelatihan pengunaan } \\
\text { aplikasi Pengurus Daerah Dewan } \\
\text { Masjid Indonesia, Membuat } \\
\text { kesepakatan agenda pelaksanaan } \\
\text { pelatihan dan disetujui untuk } \\
\text { membuat grup whatsapp sebagai } \\
\text { media komunikasi }\end{array}$ \\
\hline 2 & $\begin{array}{l}\text { Tahap Uji Coba: } \\
\text { Menyiapkan aplikasi dewan masjid } \\
\text { indoensia (DMI) untuk pengelolaan } \\
\text { produk dan kegiatan masjid Kota } \\
\text { Semarang }\end{array}$ & $\begin{array}{l}\text { Peserta mendapatkan pengetahuan } \\
\text { berupa pelatihan, peserta } \\
\text { mendapatkan fasilitas media } \\
\text { komunikasi dan prosedur } \\
\text { penggunaan aplikasi Dewan }\end{array}$ \\
& $\begin{array}{l}\text { Masjid Indoensia (DMI) Kota } \\
\text { Semarang }\end{array}$ \\
\hline 3 & $\begin{array}{l}\text { Tahap Bimbingan Teknis: } \\
\text { Menyiapkan aplikasi Dewan Masjid } \\
\text { Indoensia (DMI) Kota Semarang secara } \\
\text { sempurna dan memberikan bimbingan }\end{array}$ & $\begin{array}{l}\text { Peserta mendapatkan bimbingan } \\
\text { teknik unuk memahami dan } \\
\text { mengoperasikan aplikasi Dwan } \\
\text { Masjid Indonesia (DMI) melalui }\end{array}$ & $100 \%$ \\
\hline
\end{tabular}


teknis kepada PD DMI Kota Semarang media Komunikasi whatsapp

\section{KESIMPULAN}

Program pengabdian masyarakat ini bermanfaat bagi Pengurus Daerah DMI Kota Semarang, Para Takmir Masjid dan masyarakat Semarang dengan luaran berupa aplikasi Dewan Masjid Indonesia (DMI) yang dapat memberikan lokasi masjid masjid dengan jarak terdekat melalui Media Komunikasi grup Whatsapp untuk pengelolaan produk dan kegiatan masjid Kota Semarang. Selain itu melalui peogram pengabdian dengan mitra ini setiap peserta pelatihan dapat mengoperasikan aplikasi tersebut baik dari sisi teknis maupun adminitratif dan didukung dengan Media Komunikasi grup Whatsapp yang bisa memberikan pelayanan informasi terkait dengan penggunaan aplikasi.

\section{SARAN}

Pelatihan Iptek bagi Masyarkat yang mencakup manajemen kegiatan organisasi dalam hal ini adalah Organisasi Pengurus Dearah Dewan Masjid Indoensia Kota Semarang. Di era industry 4.0 ini hampir semua kegiatan menggunakan Internet dan gadget untuk mengakses informasi sehingga di perlukanya sebuah platform (aplikasi) yang mewadahi seluruh kegiatan organisasi, seingga memudahkan seluruh anggota pengurus daerah baik panitia, takmir, maupun jamaah dalam berkomunikasi satu dengan yang lain. Saran untuk kegiaatan ini berupa pelaksanaan bimbingan teknik aplikasi DMI Kota Semarang sebaiknya dilakukan di laboraturium agar semua panitia, taknir, dan jamaah dapat mengakses, menggunakan dan memahami setiap fungsi yang ada dalam aplikasi.

\section{UCAPAN TERIMA KASH}

Termakasih kami ucapkan kepada Lembaga Pengabdian Masyarakat Universitas Dian Nuswantoro yang telah memberikan fasilitas dan dukungan yang diberikan kepada kami dan PD DMI Kota Semarang, sehingga kegiatan pengabdian ini dapat berjalan dengan lancar.

\section{DAFTAR PUSTAKA}

[1] B. P. Statistik And K. Semarang, "Pusat Informasi Publik Balaikota Semarang," 2017.

[2] S. A. And R. F. R. M A Muchtar, M F Syahputra, N Syahputra1, "Augmented Reality For Searching Potential Assets In Medan Using Gps Based Tracking Augmented Reality For Searching Potential Assets In Medan Using Gps Based Tracking," 2017.

[3] D. Abdullah And U. Malikussaleh, "Aplikasi Database Masjid Berbasis Web Gis," No. January 2015, 2017.

[4] S. P. Muhammad Sholeh, "Aplikasi Mobile Pencari Masjid Dan Mushola Di Wilayah Daerah Istimewa Yogyakarta Dengan Google Maps آذر,” Vol. 8, No. 33. P. 44, 2014.

[5] D. M. Isnaeni, F. Mintarsih, And F. Fahrianto, "Implementasi Algoritma Meeus Dalam Penentuan Waktu Shalat Dan Pencarian Masjid Terdekat," Vol. 8, No. 1, Pp. 1-10, 2015. 